\title{
TEN CASES OF MALIGNANT HYPERTHERMIA IN NORWAY
}

\author{
J. Stovner, K.R. InNes, ANd A. Holen*
}

SIXCE 1967 ten cases of malignant hyperthermia (MH) have been reported at the annual meetings of the Norwegian anaesthesiologists. The present paper is a condensed report of these cases with a discussion of the presented data.

The data have been presented in four tables. The patients are numbered from one to ten in chronological order. The MH incidents occurred over a ten-y'ear period, with the first case in 1965 and the last in 1975 . New features like creatine phosphokinase (CPK) determinations and procaine infusions therefore only appear in the more recent cases.

\section{Discussion of the Data}

Age and sex related to mortulity

Eight of our ten patients were between 11 and 20 years of age (Table I). The series of $\mathrm{MH}$ victims published by other authors also have the highest incidence in the second decade of life. ${ }^{1-3}$ In comparing the age of mortality Gjengst $\phi^{2}$ found a mortality in the second decade almost double that in the first decade. This indicates a dramatic change in the severity of the condition with puberty and our series seems to support the view that such a change occurs. Of our eight teen-aged patients, only one (number 9) survived. Both our prepuberty patients, however, were resuscitated. This increase in mortality with puberty, is not often mentioned in the literature.

The grenetic defect in $\mathrm{MH}$ is a dominant autosomal trait. ${ }^{\text {T }}$ This might seem strange in view of the fact that in all the published series of $\mathrm{MH}$ victims there is a surplus of males. ${ }^{1-:}$ This is also the case in our series which has a ratio of males/ females of 8:2. It must be remembered, however, that an autosomal trait might depend on hormonal factors for its penetrance. Such, for instance, is the case with baldness, another autosomal genetic defect which only becomes manifest under the influence of androgens. The genetic defect in MH might also be facilitated in its penetrance by androgens. This hypothesis is supported by the male preponderance of the $\mathrm{MH}$ victims as well as by the fact that the severity of the syndrome in the male increases with puberty. In our series all seven fatal cases were males who had rcached sexual maturity.

The possible facilitation of the MH syndrome by androgens is of interest in connection with the occurrence of $\mathrm{MH}$ in one of our patients (number 7 ) afflicted with the adrenogenital syndrome. The infrequency of the $\mathrm{MH}$ complication $(1: 1,400),{ }^{1}$ and the even more rare adrenogenital syndrome $(1: 67,000),{ }^{5}$ makes a coincidence by chance very unlikely. A possible explanation is that the excessive

"Department of Anaesthesia, Rikshospitalet, Oslo, Norway, and Department of Anaesthesia, Central Hospital, Molde, Norway. 
TABLE ।

Age, Sex, CPK Valdes, Fanily Data and Previols Anatesthetics

\begin{tabular}{|c|c|c|c|c|c|}
\hline $\begin{array}{c}\text { Case } \\
\text { number }\end{array}$ & Age & $\operatorname{Sex}$ & $\begin{array}{l}\text { CPK values } \\
\text { of patient }\end{array}$ & $\begin{array}{l}\text { Family history } \\
\text { CPK values }\end{array}$ & Previous anaesthetics \\
\hline 1. & 18 & Male & Unknown & Healthy family & None \\
\hline 2 & 19 & Male & Unknown & $\begin{array}{l}\text { Father } \\
\text { pes equinovarus }\end{array}$ & $\begin{array}{l}\text { Uncomplicated gas- } \\
\text { ether two years } \\
\text { previously }\end{array}$ \\
\hline 3 & 15 & Male & Unknown & Healthy family & $\begin{array}{l}\text { Uncomplicated ether } \\
\text { two years previously }\end{array}$ \\
\hline 4 & 13 & Male & Unknown & Healthy family & None \\
\hline 5 & 17 & Male & Unknown & $\begin{array}{l}\text { Mother CPK }=250 \\
\text { Brother CPK }=125\end{array}$ & $\begin{array}{l}\text { Five days previously } \\
\text { halothane-suxameth- } \\
\text { onium six blood trans- } \\
\text { fusions. No reactions }\end{array}$ \\
\hline 6 & 15 & Male & Unknown & $\begin{array}{l}\text { Parents and brother } \\
\text { normal CPK }\end{array}$ & $\begin{array}{l}\text { Three yenrs before } \\
\text { stiffness and nyo- } \\
\text { globinuria after } 10 \mathrm{~min}- \\
\text { ute halothane } \\
\text { anaesthesia }\end{array}$ \\
\hline 7 & $4 \frac{1}{2}$ & $\begin{array}{l}\text { Female } \\
\text { (pseudo- } \\
\text { hermaph- } \\
\text { rodite) }\end{array}$ & $\mathrm{CPK}=200$ & $\begin{array}{l}\text { Parents not related. } \\
\text { Sister also adreno- } \\
\text { genital syndr. }\end{array}$ & $\begin{array}{l}\text { The patient and sister } \\
\text { uncomplicated N2O+ } \\
\text { halothane at the age of } \\
\text { two. }\end{array}$ \\
\hline S & 16 & & Unknown & $\begin{array}{l}\text { Healthy family } \\
\text { Mother CPK =644 } \\
\text { Sister CPK = 74 }\end{array}$ & None \\
\hline 9 & 15 & Male & $\mathrm{Cl} \mathrm{K}=45$ & Brother $\mathrm{CPK}=75$ & $\begin{array}{l}\text { Uneventful ether at: } \\
\text { the age of seven }\end{array}$ \\
\hline 10 & 10 & Female & $\mathrm{CPK}=100$ & $\begin{array}{l}\text { Healthy family } \\
\text { Nother CPK = 40 } \\
\text { Sister CPK }=; ;=5\end{array}$ & None \\
\hline
\end{tabular}

Upper normal limits for CPK. Males: 35., Females: 20. Children: 20.

formation of androgens in patients with the adrenogenital syndrome acts as a predisposing factor for the $\mathrm{MH}$ complication. This is also in agreement with the uncomplicated aniesthesia in our patient number 7 at the age of two years, bccause at that age excessive secretions of androgens had not yet started. We have not found any previous reports in the literature of XH occurring in patients with the adrenogenital syndrome. It is possible that this rare coincidence occurred because excessive androgen secretion facilitates the manifestation of the MHI symdrome. The importance of androgens for the porcine MH cannot readily be determined because most pigs are castrated at an early age. It has been suggested, however, that the MH-prone Pietrain pigs represent a race with androgenic overactivity. ${ }^{6}$

\section{CPK determinations}

This was clone on the near relatives of the last six patients. Borderline values as well as values well above the normal were found for several of the relatives, although some of them had been subjected previously to anaesthetics without complications. This confirms the report that general anaesthesia may not produce 
TABLE II

Conditions requiring Surgery and Surgery Performed

\begin{tabular}{|c|c|c|}
\hline $\begin{array}{c}\text { Case } \\
\text { number }\end{array}$ & Conditions requiring surgery & Surgery performed or intended \\
\hline 1 & Finger injury 2 weeks previously & Plastic finger surgery intended \\
\hline 2 & $\begin{array}{l}\text { Traffic accident with nasal fracture } \\
6 \text { days previously }\end{array}$ & Reduction of nasal fracture intended \\
\hline 3 & Elbow fracture 2 weeks previously & $\begin{array}{l}\text { Open reduction of elbow fracture } \\
\text { intended }\end{array}$ \\
\hline 4 & $\begin{array}{l}\text { Femoral bone cy'st, congenital, } \\
\text { causing symptoms }\end{array}$ & $\begin{array}{l}\text { Angiography followed by operation was } \\
\text { intended }\end{array}$ \\
\hline i) & $\begin{array}{l}\text { Traffic accident with shock five days } \\
\text { previously }\end{array}$ & $\begin{array}{l}\text { Reduction and fixation of leg fracture } \\
\text { intended }\end{array}$ \\
\hline 6 & Cryptorchiclism & Orchidopexy intended \\
\hline 7 & $\begin{array}{l}\text { Adrenogenital syndrome type I. Salt } \\
\text { loser. Penile clitoris }\end{array}$ & $\begin{array}{l}\text { Clitoris extirpation intencled but only } \\
\text { partly performed }\end{array}$ \\
\hline 8 & Appendicitis acute & Appendectony performed \\
\hline 9 & $\begin{array}{l}\text { Fracture-clislocation of tibiai } \\
\text { tuberosity two days previously }\end{array}$ & Open reduction and fixation performed \\
\hline 10 & $\begin{array}{l}\text { Cold appendicitis. Suffered appen- } \\
\text { dicitis with peritonitis three months } \\
\text { previously }\end{array}$ & Appendectomy intended \\
\hline
\end{tabular}

adverse effects in individuals with CPK values above normal limits. In the three patients who survived, the CPK levels rose 15 to 100 times their normal values in the first days after the $\mathrm{MH}$ incidents. After a week, the CPK fell to normal limits in one patient while in the other two it remained above normal. This confirms the general opinion expressed by Britt in $1974^{\circ}$ that CPK determinations are unreliable as a diagnostic indicator.

\section{Indications for surgery}

Indications for elective orthopedic surgery were present in six of our patients (Table II). Also in other series orthopedic surgery was the most frequent type of operation to be performed. ${ }^{1}$ One of our patients was treated for cryptorchidism, an indication for surgery present in five of the $18 \mathrm{MH}$-victims reported by King, et al." This condition was also present bilaterally in a patient suffering two episodes of $\mathrm{MH}$ on different occasions, reported by Katz. "Genital surgery was performed on the 4\%-year-old pseudohermaphrodite girl in our series. It is possible that young people due to undergo genital surgery are potential victims for $\mathrm{MH}$. Such conditions are frequently congenital and congenital abnormalities vere present in 30 per cent, 25 per cent and 50 per cent of previously reported series. ${ }^{1-3}$ Among our orthopedic cases patient number 2 had a congenital patellar luxation and pes equinovarus like his father and therefore belongs to this category. The same may apply to our patient number 4 who had a congenital femoral bone cyst which was to be opened and filled with bone.

It is quite possible that some of the pathological conditions requiring surgery among our patients increased the sensitivity to suxamethonium. Such could be the case with five of our orthopedic patients who had suffered traumatic injuries only 
TABLE III

Preoperative Condition, Premedication, Axaesthesia Jnduction and Majutexance

\begin{tabular}{|c|c|c|c|c|c|c|}
\hline $\begin{array}{l}\text { Case } \\
\text { number }\end{array}$ & $\begin{array}{c}\text { Preope } \\
\text { Tem- } \\
\text { perature }\end{array}$ & $\begin{array}{l}\text { rative } \\
\text { Condition }\end{array}$ & $\begin{array}{l}\text { Premedic } \\
\text { (one hour }\end{array}$ & $\begin{array}{l}\text { cation } \\
\text { preop.) }\end{array}$ & $\begin{array}{l}\text { Anaesthesia } \\
\text { induction }\end{array}$ & $\begin{array}{l}\text { Anaesthesia } \\
\text { maintenance }\end{array}$ \\
\hline 1 & $37.1^{\circ} \mathrm{C}$ & Good & $\begin{array}{l}\text { Morphine } \\
\text { Scopolam }\end{array}$ & $\begin{array}{c}10 \mathrm{mg} \\
0.4 \mathrm{mg}\end{array}$ & $\begin{array}{l}\text { Thiopentone } \\
\text { Suxamethonium } \\
\text { Jaw still ness }\end{array}$ & $\mathrm{N}_{2} \mathrm{O}+$ Halothane \\
\hline 2 & $37^{\circ} \mathrm{C}$ & Good & $\begin{array}{l}\text { Meperidine } \\
\text { Atropine }\end{array}$ & $\begin{array}{l}50 \mathrm{mg} \\
0.6 \mathrm{mg}\end{array}$ & $\begin{array}{l}\text { Thiopentone } \\
\text { Suxamethonium }\end{array}$ & $\mathrm{N}_{2} \mathrm{O}+$ Halothane \\
\hline 3 & $37.1^{\circ} \mathrm{C}$ & Good & $\begin{array}{l}\text { Neperidine } \\
\text { Atropine } \\
\text { Phenergan }\end{array}$ & $\begin{array}{cc}50 & \mathrm{mg} \\
0.5 & \mathrm{mg} \\
25 & \mathrm{mg}\end{array}$ & $\begin{array}{l}\text { Thiopentone } \\
\text { Halothane }\end{array}$ & $\mathrm{N}_{2} \mathrm{O}+$ Halothane \\
\hline 4 & $36.6^{\circ} \mathrm{C}$ & Good & $\begin{array}{l}\text { Meperidine } \\
\text { Atropine } \\
\text { Phenergan }\end{array}$ & $\begin{array}{r}50 \quad \mathrm{mg} \\
0.6 \mathrm{mg} \\
25 \quad \mathrm{mg}\end{array}$ & $\begin{array}{l}\text { Thiopentone } \\
\text { Suxamethonium } \\
\text { Halothane }\end{array}$ & $\mathrm{X}_{2} \mathrm{O}+$ Halothane \\
\hline 5 & $37^{\circ} \mathrm{C}$ & Good & $\begin{array}{l}\text { Meperidine } \\
\text { Atropine }\end{array}$ & $\begin{array}{r}35 \mathrm{mg} \\
0.5 \mathrm{mg}\end{array}$ & $\begin{array}{l}\text { Hexobarbital } \\
\text { Suxamethonium } \\
\text { Jaw stiffness }\end{array}$ & $\mathrm{N}_{2} \mathrm{O}+$ Halothane \\
\hline 6 & $37^{\circ} \mathrm{C}$ & Crood & $\begin{array}{l}\text { Meperidine } \\
\text { Atropine }\end{array}$ & $\begin{array}{c}50 \mathrm{mg} \\
0.5 \mathrm{mg}\end{array}$ & $\begin{array}{l}\text { Hexobarbital } \\
\mathrm{N}_{2} \mathrm{O}+\text { Halothane }\end{array}$ & $\mathrm{X}_{2} \mathrm{O}+$ Halothane \\
\hline 7 & $37.7^{\circ} \mathrm{C}$ & Giood & $\begin{array}{l}\text { Atropine } \\
\text { Cortisone }\end{array}$ & $\underset{75}{0.5 \mathrm{mg}}$ & $\begin{array}{l}\mathrm{N}_{2} \mathrm{O}+\mathrm{Halo}- \\
\text { thane }\end{array}$ & $\mathrm{N}_{2} \mathrm{O}+$ Halothane \\
\hline 8 & $38.7^{\circ} \mathrm{C}$ & Good & $\begin{array}{l}\text { Meperidine } \\
\text { Atropine }\end{array}$ & $\begin{array}{r}50 \mathrm{mg} \\
0.5 \mathrm{mg}\end{array}$ & $\begin{array}{l}\text { Thiopentone } \\
\mathrm{N}_{2} \mathrm{O}+\text { Halothane }\end{array}$ & $\mathrm{N}_{2} \mathrm{O}+$ Halothane \\
\hline 9 & $37.2^{\circ} \mathrm{C}$ & Good & $\begin{array}{l}\text { Diazepam } \\
\text { Atropine }\end{array}$ & $\begin{array}{l}12.5 \mathrm{mg} \\
0.5 \mathrm{mg}\end{array}$ & $\begin{array}{l}\text { Thiopentone } \\
\text { Suxamethonium } \\
\text { Jaw stiflness }\end{array}$ & $\mathrm{X}_{2} \mathrm{O}+$ Halothane \\
\hline 10 & $30.9^{\circ} \mathrm{C}$ & Good & Atropine & $0.5 \mathrm{mg}$ & $\begin{array}{l}\text { Hexobarbital } \\
\text { Suxamethonium } \\
\text { Jaw stillness } \\
\text { Temp. } 38.1^{\circ} \mathrm{C}\end{array}$ & $\begin{array}{l}100_{i i}^{c} O_{2} \text { ventila- } \\
\text { tion }\end{array}$ \\
\hline
\end{tabular}

a few days previously. Several workers have shown that trauma sensitizes the muscles to suxamethonium. ${ }^{10-12}$ Also the planned appendectomy in our patient number 10 who had suffered an attack of appendicitis with fever and peritonitis three months previously might belong to this category. It has recently been reported that after febrile illnesses with sepsis or peritonitis, the patients react to suxamethonium with excessive muscle stiffness and potassium liberation. ${ }^{1: 3}$ The rigidity, hyperpyrexia and rise in CPK in our patient number 10 after $100 \mathrm{mg}$ suxamethonium indicates an excessive sensitivity to this drug which might have been induced by the previous attack of appendicitis. Thanks to early diagnosis and prompt treatment, this patient was saved.

\section{Premedication and anaesthetics used}

All our patients had received anticholinergic premedication, atropine in nine cases and scopolamine in one (Table II). Rigidity appeared in all our patients except one (number 2). The high percentage of rigidity in our series (90 per cent) supports the original finding that anticholinergic premedication increases the tendency to rigidity, ${ }^{1}$ Later, however, it has been suggested that the combination of atropine-suxamethonium was the cause of the high frequency of rigidity. ${ }^{1+}$ This 
does not quite agree with our series as three of our patients (numbers 6, 7 and 8) received no suxamethonium and nevertheless displayed frank rigidity. This rigidity must have been caused by either $\mathrm{N}_{2} \mathrm{O}$ or halothane which was given in combination in our patients. Halothane was shown originally to trigger porcine $\mathrm{MH}^{15}$ and has been shown later to cause contracture of isolated muscle strips obtained from $\mathrm{MH}$ victims. ${ }^{16} \mathrm{~N}_{2} \mathrm{O}$ was regarded as innocent up to 1974 when Ellis, et al. ${ }^{17}$ described a patient developing $\mathrm{MH}$ on two occasions after being given only $\mathrm{N}_{2} \mathrm{O}$ and oxygen. As nitrous oxide has been used in almost all cases so far reported and regarded as innocent, all the previously made statements and conclusions are open to question. Our patient number 6 must have been permanently and excessively sensitive to one or both of these inhalation agents. During the fatal anaesthesia he breathed these agents for only 15 minutes. Three years previously, he had developed muscle stiffness and red urine (myoglobin) for two days following a 10-minute inhalation of the same agents. This incident had been duly recorded in the case history but passed unnoticed because of language difficulties, as the anaesthetist was of foreign nationality.

Suxamethonium rigidity in the jaw muscles during induction is important as a warning signal to end anaesthesia at once. ${ }^{18}$ This sign occurred in numbers $1,5,9$ and 10 of our patients, but it was only in the last patient that the anaesthetist took notice and cancelled further work, a decision which probably saved the patient's life. A similar aborted $\mathrm{MH}$ case has recently been described. ${ }^{19}$ This shows that jaw stiffness during induction is a sign which should be taken seriously by the anaesthetist.

\section{Management of the cases}

In all our cases anaesthesia was terminated as soon as the diagnosis was made, cooling by various means was started and hyperventilation with pure oxygen performed. Intravenous infusions of various solutions were set up, such as bicarbonate, THAM, lactated Ringer's solution, mannitol, saline and plasma expanders. In addition, various drugs were given (Table IV).

The drug therapy of the three survivors is of some interest. Patient number 7, the 4\%-year-old girl with the adrenogenital syndrome, received hydrocortisone and chlorpromazine $5 \mathrm{mg}$ together with bicarbonate infusion. This reduced the rigidity and lowered the temperature so procaine infusion was omitted. Patient number 9 , a 15-year-old boy, received hydrocortisone $200 \mathrm{mg}$ and lanatocid $0.8 \mathrm{mg}$ intravenously together with bicarbonate and lactated Ringer's infusion. This raised the blood pressure from shock levels to $100 \mathrm{~mm} \mathrm{Hg}$, but pyrexia, rigidity and tachycardia with arrythmia persisted. Procaine $3.5 \mathrm{~g}$ was therefore infused over 60 minutes, resulting in disappearance of the rigidity and normalization of cardiac rate, rhythm and temperature without fall in blood pressure. Patient number 10 , a 10 -ycar-old girl, received hexobarbitone $500 \mathrm{mg}$ followed by halothane 2 per cent for two minutes and then suxamethonium $100 \mathrm{mg}$. Intubation, however, was abandoned because of jaw rigidity and anaesthesia was terminated. Less than 10 minutes had elapsed from the time of the barbiturate injection until a diagnosis of $\mathrm{MH}$ was made, based on jaw stiffness and hyperpyrexia (temperature $38.1^{\circ} \mathrm{C}$ ). Hyperventilation prevented the development of acidosis but did not prevent body 
TABLE IV

First Symptoms, Course and Treatment and Final Outcome

\begin{tabular}{|c|c|c|c|}
\hline $\begin{array}{c}\text { Case } \\
\text { number }\end{array}$ & $\begin{array}{l}\text { Time after induction } \\
\text { for first symptoms }\end{array}$ & Course and treatment & Final outcome \\
\hline 1 & $\begin{array}{l}\text { After } 20 \text { min rigidity, } \\
\text { temp. } 39.4^{\circ} \mathrm{C} \text {, tachy- } \\
\text { cardia arrythmia }\end{array}$ & $\begin{array}{l}\text { pH } 6.8 \text { in arterial blood. } \\
\text { Cooling, bicarb., } \\
\text { defibrillation }\end{array}$ & $\begin{array}{l}\text { Declared dead } 60 \mathrm{~min} \text { after } \\
\text { induction. General rigidity }\end{array}$ \\
\hline 2 & $\begin{array}{l}\text { After } 60 \text { min tachy- } \\
\text { cardia, hypertension, } \\
\text { temp. }=42^{\circ} \mathrm{C} \text {. No rigid. }\end{array}$ & $\begin{array}{l}\text { Cardiac arrest. THAN } \\
\text { cooling, mannitol }\end{array}$ & $\begin{array}{l}\text { Declared dead six hours } \\
\text { after induction. No } \\
\text { rigidity }\end{array}$ \\
\hline 3 & $\begin{array}{l}\text { After } 20 \text { min cardiac } \\
\text { arrest, temp. }=40.6^{\circ} \mathrm{C} \text {. } \\
\text { No rigidity }\end{array}$ & $\begin{array}{l}\text { Cooling, calcium, defi- } \\
\text { brillation, arrythmia, } \\
\text { lidocaine, rigidity }\end{array}$ & $\begin{array}{l}\text { Declared dead } 36 \text { hours } \\
\text { after induction with myo- } \\
\text { globinuria, haemolysis, } \\
\text { hyperkalaemia, rigidity }\end{array}$ \\
\hline 4 & $\begin{array}{l}\text { After } 60 \text { min rigidity, } \\
\text { respiratory arrest, } \\
\text { temp. }=42^{\circ} \mathrm{C} \text {, tachy- } \\
\text { cardia }\end{array}$ & $\begin{array}{l}\text { Ventricular fibrillation, } \\
\text { bicarbonate, defibril- } \\
\text { lation }\end{array}$ & $\begin{array}{l}\text { Declared dead } 90 \text { min after } \\
\text { induction with general } \\
\text { rigidity }\end{array}$ \\
\hline$\therefore$ & $\begin{array}{l}\text { After } 20 \text { min rigidity, } \\
\text { temp. }=42^{\circ} \mathrm{C} \text {. Cyanosis }\end{array}$ & $\begin{array}{l}\text { Bradycardia, ventricular } \\
\text { fibrillation, defibrillation }\end{array}$ & $\begin{array}{l}\text { Declared dead } 50 \text { min after } \\
\text { induction with general } \\
\text { rigidity }\end{array}$ \\
\hline 6 & $\begin{array}{l}\text { After } 15 \text { min rigidity, } \\
\text { hyperventilation, } \\
\text { temp. }=42.5^{\circ} \mathrm{C} \\
\text { Cardiac arrest }\end{array}$ & $\begin{array}{l}\text { Cooling, cortisone bi- } \\
\text { carbonate, dextran } \\
\text { bradycardia, isoprenaline }\end{array}$ & $\begin{array}{l}\text { Declared dead } 90 \text { min after } \\
\text { induction with general } \\
\text { rigidity }\end{array}$ \\
\hline 7 & $\begin{array}{l}\text { After } 30 \text { min hyperventi- } \\
\text { lation, rigidity, cyanosis, } \\
\text { tachycardia, } \\
\text { temp. }=42^{\circ} \mathrm{C}\end{array}$ & $\begin{array}{l}\text { Cooling, bicarbonate, } \\
\text { hydrocortisone, chlor- } \\
\text { promazine }\end{array}$ & $\begin{array}{l}\text { Patient survived after a } \\
\text { period of hypothermia }\end{array}$ \\
\hline 8 & $\begin{array}{l}\text { After } 40 \text { min hyperventi- } \\
\text { lation, tachycardia, } \\
\text { rigidity, temp. }=42^{\circ} \mathrm{C}\end{array}$ & $\begin{array}{l}\text { Convulsions, cardiac } \\
\text { arrest during cooling and } \\
\text { bicarbonate infusion }\end{array}$ & $\begin{array}{l}\text { Declared dead } 2 \frac{1}{2} \text { hours } \\
\text { after induction with general } \\
\text { rigidity }\end{array}$ \\
\hline 9 & $\begin{array}{l}\text { After } 30 \text { min tachycardia } \\
\text { arrythmia, temp. }=40^{\circ} \mathrm{C} \\
\text { rigidity, collapse }\end{array}$ & $\begin{array}{l}\text { Cooling, bicarbonate, } \\
\text { Ringer, hydrocortisone } \\
\text { procaine } 3.5 \mathrm{~g} \text { i.v. }\end{array}$ & $\begin{array}{l}\text { Patient survived after a } \\
\text { period with hypothermia }\end{array}$ \\
\hline 10 & $\begin{array}{l}\text { After } 2 \text { min jaw stiliness. } \\
\text { Anaesthesia ended } 10 \mathrm{~min} \\
\text { after start }\end{array}$ & $\begin{array}{l}\text { Temp. reached } 41.3^{\circ} \mathrm{C} \text {. } \\
\text { Cooling and hyperventi- } \\
\text { lation with oxygen. } \\
\text { Procaine } 1 \mathrm{~g}\end{array}$ & $\begin{array}{l}\text { Patient survived after a } \\
\text { period with hypothermia }\end{array}$ \\
\hline
\end{tabular}

temperature from rising to $41.3^{\circ} \mathrm{C}$. Immersion in ice water caused the temperature to fall. Persistence of rigidity was also treated in this case with procaine $1 \mathrm{~g}$ intravenously without fall in blood pressure.

\section{Procaine therapy}

Procaine therapy was first suggested by Harrison ${ }^{20}$ followed by Moulds and Denborough. 2 The clinical effects of procaine reported in the literature seems to be variable. A good effect on both rigidity and temperature was found by two groups of workers, ${ }^{22.23}$ while a third found no effect on temperature. ${ }^{24}$ Fatal hypotension accurred after only $600 \mathrm{mg}$ of procaine in a patient recently reported. .5 In this case procaine was given initially before correction of acidosis. This is contrary to Harrison's ${ }^{20}$ original routine, although other workers have proposed to start procaine initially. ${ }^{26}$ Our patient number 9 tolerated procaine $3.5 \mathrm{~g}$, a very 
large dose. The absence of blood pressure fall might be due to the fact that acidosis had been corrected before the infusion.

\section{Steroid therapy}

Hydrocortisone $100 \mathrm{mg}$ together with chlorpromazine $5 \mathrm{mg}$ appeared to be effective in patient number 7 . Dexamethasone was shown by Ellis, et al. ${ }^{17}$ to work very effectively on two occasions in the same patient. Our patient number 9 also received hydrocortisone $200 \mathrm{mg}$, which appeared to arrest the temperature rise and raise the blood pressure. The persisting rigidity and tachycardia, however, responded to procaine. Also in patient number 10 residual rigidity subsided with procaine.

Our experience would therefore indicate that procaine should be reserved until other measures, such as cooling, correction of acidosis and steroid therapy have been tried. Incidentally, this conclusion reached from clinical experience is in agreement with conclusions reached experimentally. ${ }^{27}$ It has been suggested that the beneficial role played by procaine at this stage is due to inhibition of catecholamine release and block of the adrenergic alpha-receptors. ${ }^{28}$ This role, however, may be played by other agents.

\section{SUMMARY}

Data are presented on ten cases of anaesthesia-induced malignant hyperthermia in Norway. Seven of the patients died, three recovered. The fatal cases were all boys in the age group 11-20 years. This age and sex distribution suggests that puberty with the increase in androgens is a precipitating factor in malignant hyperthermia. One of the victims who survived was a 4,2-year-old pseudohermaphrodite girl with the adrenogenital syndrome. The coincidence of malignant hyperthermia in a patient with such a rare syndrome points to the excessive formation of androgens in patients with this syndrome as a predisposing factor.

The indications for surgery were traumatic injuries in five cases, congenital abnormalities in three and appendicitis in two cases. These conditions in themselves may cause an increased sensitivity to suxamethonium.

One patient received only hexobabitonc, halothane and suxamethonium. After the last drug jaw rigidity and temperature rise to $41.3^{\circ} \mathrm{C}$ prompted the anaesthetist to end the anaesthetic. The fact that the patient survived proves that suxamethonium induced jaw rigidity is valuable as a warning.

The absence of cardiovascular depression after procaine $3.5 \mathrm{~g}$ in one patient is ascribed to the correction of acidosis at the time of infusion of this drug. It is suggested that procaine should be withheld until other measures such as cooling, correction of acidosis and steroid therapy have been tried.

\section{RÉSUMÉ}

Dix cas d'hyperthermie maligne survenus en Norvège sont rapportés et discutés. Sept des dix patients sont morts et trois ont survécu. Tous les décès sont survenus chez des garçons âgés de onze à vingt ans, ce qui suggère que la période de puberté 
qui s'accompagne d'une augmentation des androgènes peut représenter un facteur déclenchant. L'un des survivantes, une petite fille de quatre ans et demi, présentait un pseudo-hermaphrodisme avec syndrome adrénogénital. Le fait d'observer une hyperthermie maligne chez une patiente présentant déjà une pathologie aussi rare nous semble indiquer que la formation excessive d'hormones androgènes que l'on retrouve dans ces cas peut agir comme facteur déclenchant de l'hyperthermie.

Cinq des patients furent opérés pour traumatismes, trois pour des malformations congénitales et deux pour appendicite. Ces trois pathologies sont en soi susceptibles d'augmenter la sensibilité à la Succinylcholine.

L'un des patients reçut seulement de l'Hexobarbitone, de l'Halothane et du Suxa methanium. A la suite de l'injection de Suxamethanium, on observa une rigidité du maxillaire et la température s'éleva à 41.3 degrés Centigrade. L'anesthésie fut arrêtée. La survie du malade illustre que la rigidité du maxillaire observée après l'injection de Suxamethanium est un signe très fiable.

On attribue à la correction préalable d'une acidose métabolique chez un malade, l'absence de dépression cardio-respiratoire notée après une dose de 3.5 grammes de Procaine. Les auteurs suggèrent de corriger l'acidose, d'administrer des Stéroides et de tenter de refroidir, avant denvenir à la Procaine.

\section{REFERENCES}

1. Burt, B.A. \& Kalow, W. Malignant hyperthermia. A statistical review. Canad. Anaesth. Soc. J. 17: 293 (1970).

2. Cjexcsto, H. Die maligne Hyperpyrexia: eine ernsthafte Narkosekoplikation. Andesthetist. 26: 299 (1971).

3. Kinc, J.O., Dennonough, M.A., \& ZAPF, P.W. Inheritance of malignant hyperthemia. Lancet 1:365 (1972).

4. Britt, B.A., Locher, W.G., \& Kalow, W. Hereditary aspects of malignant hyperthemia. Canad. Anaesth. Soc. J. 16:89 (1969).

5. Standiuny, J.B., Wynganden, J.B., \& Fredrickson, D.S. The metabolic basis of inherited disease. McGraw-Hill. 1972, N.Y. p. 302.

6. BAALsnud, N.I. Biologiske aspekter og avlsmessige betenkeligheter. Medlemsbl. norske Voterinierforen 18: 114 (1966).

7. Oives, G. \& Kerhy, RJ. Anaesthesia during raised creatine phosphokinase activity. Brit. med. J. 4: $75(1974)$.

8. BurT, B.A. Malignant hyperthermia: A pharmacogenetic disease of skeletal muscle. New England ]. Med. 1140 (1974).

9. KATz, D. Recurrent malignant hyperpyrexia during anaesthesia. Anaesth. \& Analg. 49: $225(1970)$.

10. Binch, A.A., Mitchell, G.D., Playfond, G.A., \& Clayton, A.L. Changes in serum potassium response to succinylcholine following trauma. J.A.M.A. 210:490 (1969).

11. Mazze, R.J., Escue, H.M., \& Houston, J.B. Hyperkalaemia and cardiovascular collapse following administration of succinylcholine to traumatized patients. Anesthesiology 31 : 540 (1969).

12. Wejntraub, H.D. Heisterkasp, D.V., \& Cooperaran, L.H. Changes in serium potassium concentration after depolarizing blockers in anaesthetized man. Brit. J. Anaesth. 41: 1048 (1969).

13. BAUEk, H. Hyperkalamie nach succinylcholine bei septisch er patienten der abdominalchirurgie. Schweiz. Cesellsch. Anaesth. u. Reanim. Basel 14-15 juin 1975.

14. KALOW, W. \& Bhit, B.A. Drugs causing rigidity in malignant hyperthermia. Lancet 2 : $390(1973)$.

15. Hanmison, G.G. Anaesthetic-induced malignant hyperpyrexia and a method for its production. Brit. J. Anaesth, 14: 844 (1969).

16. Ellis, F.R., Harriman, D.G.F., Keany, N.P., Kyei-Mensah, K, \& Tyrell, J.H. Halothane-induced muscle contracture as a cause of hyperpyrexia. Brit. J. Anaesth. 43: 721 (1971). 
17. Ellis, F.R., Clalike, I.M.C., Appleyeard, T.N., \& Drusdale, R.C.W. Malignant hyperprrexia induced by nitrous oxide and treated with dexamethasone. Brit. med. ., 4: 270 (1974)

18. Reltox, J.E.S., Stewalu, D.J., Cheightox, R.E., \& Bnitr, B.A. Malignant hyperpyrexia. A theripentic and investigative regimen. Can. Anaesth. Soc. J. 19: 200 (1972).

19. Corbaloo, A.S. Aborted malignant hyperthermia. Case report. Canad. Anaesth. Soc. I. 22: $227(1975)$.

20. Hanmsox, G.G. Anaesthetic-induced malignant hyperpyrexia: a suggested method of treatment. Brit. J. Anaesth. 43: 454 (1971).

21. Moulus, R.F.W. \& Dexuorough, M.A. Procaine in malignant hyperpyrexia. Brit. med. T. 4:526(1972).

22. Belodays, J., Siall, V., Cooper, D.A., \& Britt, B.A. Post-operative malignant hyperthermiil. Calse report. Can. Anaesth. Soc. J. 21:96 (1971).

23. Bressin, J. Procainamide therapy of malignant hyperthermia, Case report. Can, Anacsth. - Soc. J. 21: 96 (1974).

24. Maisel, R.H., Sessioss, D.G., \& Millen, R.N. Malignant hyperthermia during general inicesthesial. Ann. otol. 82: 729 (1973).

25. Maclachlax, D. \& Fombist, A.L. Procaine in malignant hyperthemia. Anaesth. \& Analg. $51: 8+1(1974)$.

26. ButT, B.A. Recent adlances in malignant hyperthermia. Anaesth. \& Analg. 51: 841 (1972).

27. Clarke, I.MI. \& Ellis, F.R. An evaluation of procaine in the treatment of malignant hyperpyrexia. Brit. ]. Anaesth. 47: 17 (1975).

28. HALL, G.M., LuCkE, J.N. \& Lister, D. Treatment of porcine malignant hiperthemia. Anatesthesia, 30: 30 (1975). 